\title{
MERCURY INJECTION CAPILLARY PRESSURE AND RESERVOIR SEAL CAPACITY OF 26 OUTCROP SAMPLES, MIOCENE TO TRIASSIC AGE
}

\author{
by \\ George W. Bolger ${ }^{1}$ and Rocky R. Reifenstuhl ${ }^{2}$
}

\begin{abstract}
Twenty-six outcrop samples from Alaska Peninsula formations (Bear Lake, 11 samples; Stepovak, two samples; Tolstoi, five samples; Staniukovich, four samples; and Kamishak, four samples) were selected from the stratigraphic section as prospective hydrocarbon seals (fig. 1). These samples were analyzed using mercury injection capillary pressure (MICP). Formations were sampled based on reservoir seal position within prospective petroleum play concepts. Outcrop lithologies with the greatest perceived seal capacity were sampled.

The best quality seals (Sneider Seal Classification, Sneider, 1997) in the sample set are Sneider Type A and are present in the Bear Lake, Kamishak, and Tolstoi Formations (table 1). Overall, the Type A seals represent approximately 40 percent of the samples collected (11 of 26) and largely consist of rock visually characterized as claystone and limestone (Kamishak limestone), but also include a few of the argillaceous siltstone and argillaceous sandstone samples. The porosity in the Type A seals ranges from 1.22 percent (Kamishak limestone) to 20.2 percent (Bear Lake argillaceous siltstone); in all cases the rocks have a finescale pore structure that supports high capillary pressures.

Type $\mathrm{C}$ seals are the next most common and account for approximately 30 percent of the samples. For the most part, they are moderately argillaceous to argillaceous siltstones. Porosity ranges from 4.82 percent (Stepovak Formation) to 18.2 percent (Bear Lake Formation). A majority of the Type $\mathrm{C}$ seal rocks have a bimodal pore structure and the lower capillary pressures associated with the larger, initial pore aperture population generally control the seal capacity. Where the Type $C$ seals have a laminated fabric that creates the bimodality, the seal quality may be higher if the laminations are oriented perpendicular, or at a high angle, to the hydrocarbon migration direction.

The Staniukovich Formation samples include one calcareous siltstone with cemented to partially-open fractures and one well-compacted sandstone; both are Type B seals. Porosity is 8.30 percent and 4.98 percent, respectively. These rocks have bimodal pore structures that do not appear to be related to the depositional fabric.

The data provided by the MICP analysis show that a significant portion of the rock types sampled as potential sealing facies represent good quality Type A and Type B seals.
\end{abstract}

\section{INTRODUCTION AND METHODOLOGY}

Public data were not previously available on the quality of potential sealing facies in the onshore Bristol Bay petroleum system. Additionally, there has been some concern as to whether good quality seals exist within the depositional settings proposed for these rocks. In order to provide an initial database to address these issues, 26 Alaska Peninsula outcrop samples were collected to test their reservoir seal capacity (fig. 1; table 1). These rock samples were selected from the stratigraphic section (fig. 2) based on the likelihood that they might act as capillary seals for a subsurface reservoir in an oil or gas play on the Alaska Peninsula or near-shore Bristol Bay basin. Formations sampled include:
- Bear Lake (Miocene; 11 samples)

- Stepovak (Oligocene; two samples)

- Tolstoi (Eocene; five samples)

- Staniukovich (Early Cretaceous; four samples)

- Kamishak (Triassic; four samples).

Seals are defined as generally ductile rocks with a very high capillary entry pressure that can dam up or stop hydrocarbon migration. Petrophysical and petrographic studies of conventional and sidewall cores from known seal-reservoir couplets of hydrocarbon-producing reservoirs provide a basis to quantify the capacity of a rock to seal a hydrocarbon column (Sneider, 1997). The most

${ }^{1}$ PetroTech Associates, 11767 Katy Freeway, Suite 320, Houston, Texas 77079

${ }^{2}$ Alaska Division of Geological \& Geophysical Surveys, 3354 College Rd., Fairbanks, Alaska 99709-3707 
important property of a seal is its pore-size distribution as measured in thin section, scanning electron microscope, and high pressure (up to 60,000 psi) air-mercury capillary pressure curves determined across bedding surfaces. Using the density difference of normal saline water and 35 degree API oil as a standard, an arbitrary scale of seal types has been developed (Sneider, 1997).

The outcrop samples collected from the measured sections, or geologic mapping grab-samples to be used for seal evaluation, were forwarded to Petrotech Associates (Houston, Texas). The pieces of rock in each sample were examined using a reflected light microscope (magnifications of $5 \mathrm{X}$ to $50 \mathrm{X}$ ) and a brief description of the rock properties was made (table 1 ). A representative portion of the bulk sample was selected for capillary pressure analysis and trimmed to a size that would fit the sample holder. The sample was then placed in a low-temperature convection oven and dried to a constant weight.

The high-pressure mercury injection capillary pressure (MICP) analysis was carried out using a Micromeritics 9420 mercury porosimeter. Penetrometers with 15 cc sample chambers were used for all analyses. Each test utilized a pressure table containing 118 separate pressure points from 1.5 to 59,500 psia, and the volume of mercury injected was measured at each point. The collected data were corrected for closure, that is, intrusion related only to the mercury conforming to the sample surface. The complete detailed analytical data set for each sample and coordinates for each sample location are presented in tabular and graphical formats in RDF 2007-3 (Loveland and others, 2007) available by contacting the State of Alaska Division of Natural Resources, Division of Geological \& Geophysical Surveys (www.dggs.dnr.state.ak.us; 3354 College Road, Fairbanks, Alaska; 907-451-5020).

The air/mercury capillary pressure data were converted to gas/water and oil/water systems assuming a gas/water surface tension of 50 dynes/cm and an oil/ water interfacial tension of $30 \mathrm{dynes} / \mathrm{cm}$. Subsequent conversion to equivalent height was made using the values in table 2 . These values are used to reflect interpreted reservoir conditions.

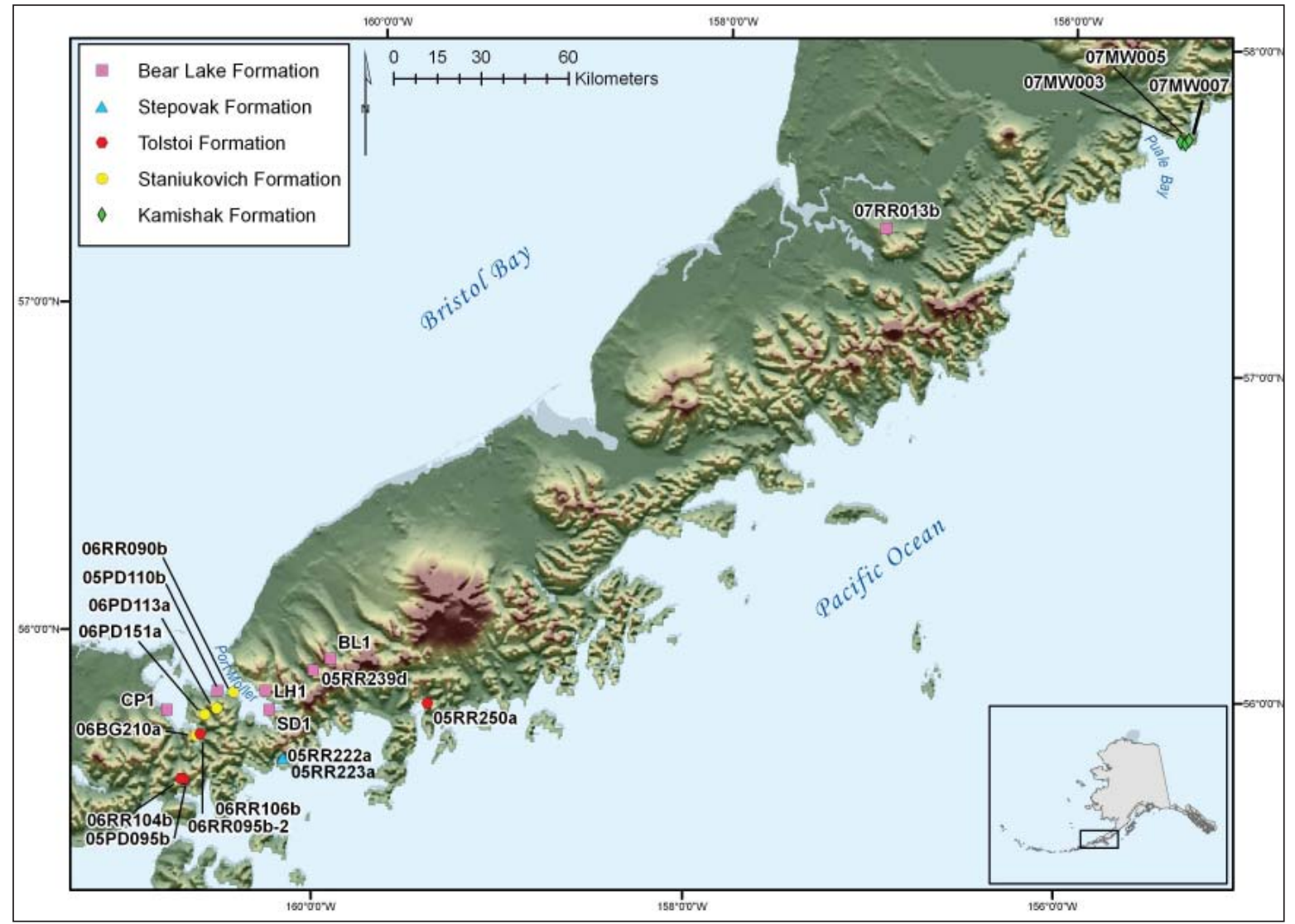

Figure 1. Map of the Alaska Peninsula showing the location of 26 outcrops sampled for mercury injection capillary pressure analyses. Samples are from the Port Moller, Puale Bay, and Ugashik Lake areas. 
Table 1. Porosity and permeability and Sneider (1997) hydrocarbon seal type derived from mercury injection capillary pressure analyses for 26 Alaska Peninsula outcrop samples. See text for discussion of Sneider seal type.

\section{Sample and Formation}

\section{Bear Lake Formation}

BL - 3

CP1 - 182

SD1 - 16

SD1 - 90

BL - 18

CP1 - 0.5

LH1 - 115

07RR013B

05PD110B

LH1 - 27.5

05RR239D

\section{Stepovak Formation}

05RR223A

05RR222A

Tolstoi Formation

05RR250A

06PD095b

06RR104b

06RR095b-2

06RR106b

Staniukovich Formation

06PD113a

06BG210

06PD151a

06RR090b

Kamishak Formation

07MW003 - 7.5

07MW005 - 50

07MW007 - 27.2

07MW003 - 46.8
MICP Derived

$\begin{array}{ccc}\text { Porosity } & \text { Permeability } & \begin{array}{c}\text { Sneider } \\ \text { (\%) }\end{array} \\ \text { (md) } & \text { Seal Type }\end{array}$

A

A

A

A

C

C

C

$\mathrm{D}$

D

E

none

\section{Description}

siltstone, argillaceous

claystone

sandstone, argillaceous, variable sandstone/siltstone/claystone, laminated, hard

siltstone, laminated argillaceous/ clean

siltstone, moderately argillaceous siltstone/sandstone, argillaceous

siltstone, laminated argillaceous/ clean

siltstone/sandstone, laminated sandstone, slightly argillaceous sandstone, reservoir (?) rock

sandstone, compacted

sandstone, argillaceous matrix

claystone

claystone

claystone

sandstone, compacted, matrix?

claystone, organic-rich, coaly

siltstone, calcareous, fractures sandstone, argillaceous, compacted siltstone, moderately argillaceous

C sandstone, argillaceous

\begin{tabular}{|c|c|c|c|}
\hline 8.3 & 0.0064 & B & siltstone, calcareous, fractures \\
\hline 4.98 & 0.0002 & B & $\begin{array}{l}\text { sandstone, argillaceous, } \\
\text { compacted }\end{array}$ \\
\hline 12.6 & 0.048 & $\mathrm{C}$ & siltstone, moderately argillaceous \\
\hline 9.33 & 0.0088 & $\mathrm{C}$ & sandstone, argillaceous \\
\hline
\end{tabular}

sandstone, compacted, cemented limestone, crystalline limestone, crystalline limestone, crystalline 
Figure 2. Stratigraphic column for the Alaska Peninsula showing rock formations with generally favorable hydrocarbon source potential (oil prone: green dots; gas prone: red dots) and hydrocarbon reservoir potential (black dots) (modified from Hite, 2004).

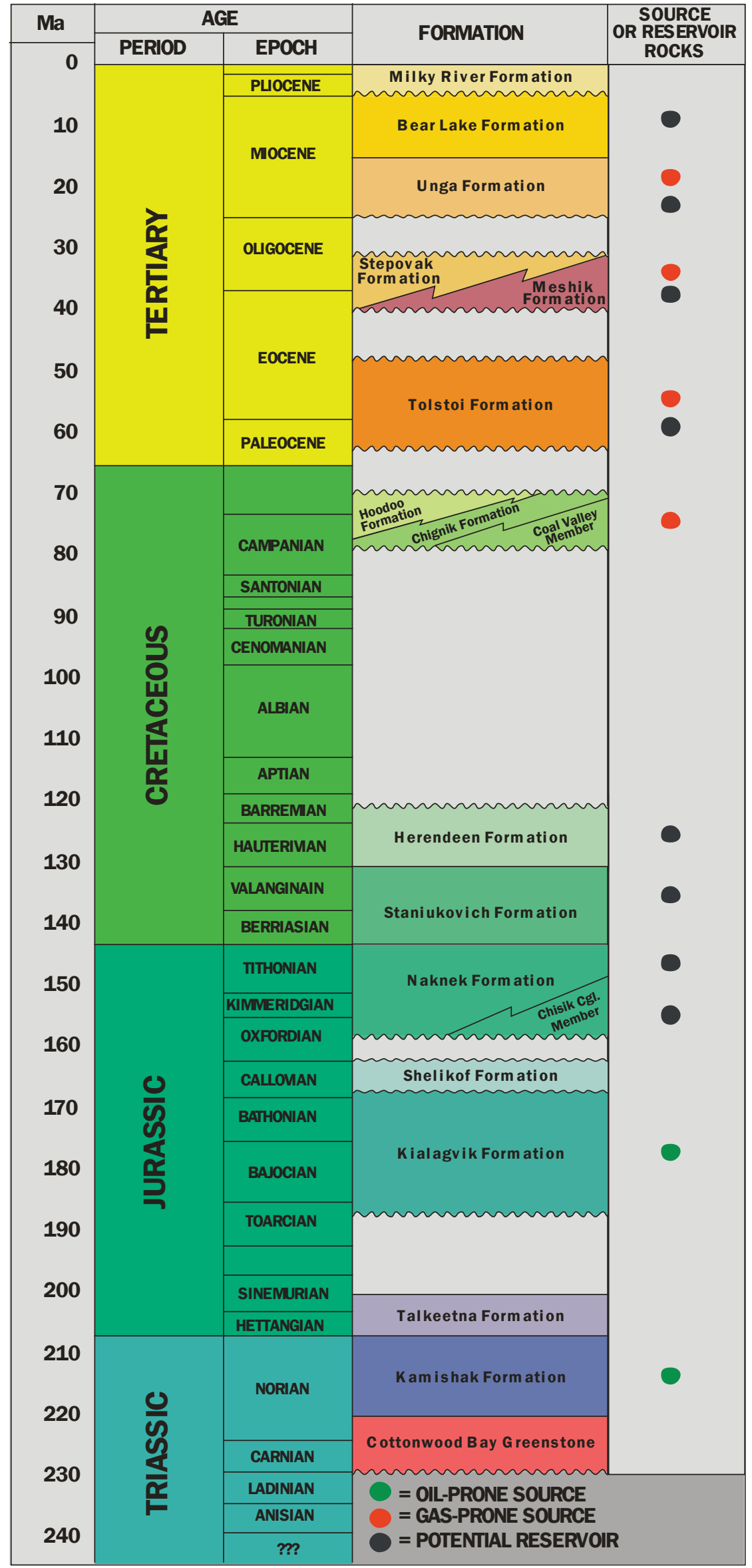




$\begin{aligned} & \text { Table 2. Values used for conversion to equivalent height } \\
& \text { of oil and gas based on the mercury injection capil- } \\
& \text { lary pressure (MICP) analyses. }\end{aligned}$
\begin{tabular}{llc} 
Water Density & Oil Density & Gas Density \\
$1.016 \mathrm{~g} / \mathrm{cc}$ & $0.28 \mathrm{~g} / \mathrm{cc}$ & $0.69 \mathrm{~g} / \mathrm{cc}$ \\
\hline
\end{tabular}

Calculations of potential seal capacity (hydrocarbon column held) were made for hydrocarbon saturations in the seal of 0 percent (entry), 5 percent, 7.5 percent, and 10 percent and are part of the available database.

Porosity and permeability values were generated for each of the samples using the MICP data. The porosity is measured using an Archimedes bulk volume and the pore volume based on the closure-corrected volume of mercury injected. Permeability is calculated using the Swanson Equation (Swanson, 1981).

\section{ROCK TYPES}

Twenty-six samples (see table 1) representing various facies and rock types were analyzed for their potential seal capacity. The samples were collected from the following formations: Bear Lake (11 samples), Stepovak (two samples), Tolstoi (five samples), Staniukovich (four samples), and Kamishak (four samples).

The appearance of the samples while being examined under reflected light microscopy indicates that they include a variety of rock types and depositional fabrics (table 1). A majority of the rocks have a grainrich character and include sandstones (nine samples), siltstones (six samples) and mixtures of the two (two samples). The grain-rich samples appear to contain limited to high levels of clay, with moderately argillaceous to argillaceous fabrics common. Samples that exhibit a more clay-rich character (that is, claystones) are less common and were primarily collected from the Tolstoi Formation. Samples containing distinctly laminated fabrics are from the Bear Lake Formation. Rock properties creating the laminae range from changes in grain size (sand to silt or silt to clay) to, more commonly, variations in clay mineral content (clean to argillaceous). Limestones that appear to have been originally slightly fossiliferous mudstones are the dominant rock in the outcrop samples from the Kamishak Formation. Locally there is visual evidence that higher levels of compaction have occurred. Only rarely do the rocks appear to have been highly cemented.

\section{PORE STRUCTURE}

The porosity and permeability based on the MICP data are listed in table 1 and displayed in figures 3 and 4, identified by formation and seal type, respectively. There is a large range in both porosity (1.22 to 37.0 percent) and permeability (0.00001 to $1.30 \mathrm{md}$ ), with the most scatter in the Bear Lake Formation samples. The higher porosity rock types tend to be argillaceous siltstones and cleaner sandstones that retain some open intergranular pore space. The lowest porosity rocks are the Kamishak Formation limestones (average 1.65 percent), followed by claystones (average 5.18 percent) and the compacted sandstones (5.53 percent) that are present in each of the formations. In the samples with the higher permeability values, a portion of the rock generally has a grain-supported fabric that contains remnant, primary intergranular pore space. However, these rocks are often laminated, resulting in inferred anisotropy.

The pore structure in the sandstones and laminated siltstone/sandstones generally exhibits some degree of bimodality; that is, there are two separate populations in the pore aperture size distribution that control access to the pore space. The two modes reflect the aperture size differences created by the change in grain size (for example, sand, silt) or open intergranular pore space versus microporous clay. The claystones, limestones, and more uniform argillaceous grain-rich rocks have relatively well defined, unimodal pore structures. This is largely a function of the more homogeneous rock fabric that produces a narrower pore aperture size distribution.

\section{SEAL QUALITY}

An assessment of seal capacity is provided by the Sneider Seal Classification (Sneider, 1997). This classification is a qualitative system for ranking seals, and is based on the mercury capillary entry pressure. Seal type, corresponding mercury capillary entry pressure, and equivalent column height for a "standard” oil water system are compiled in table 3.

The best quality seals (Sneider, 1997) in the sample set are Sneider Type A and are present in the Bear Lake, Kamishak, and Tolstoi Formations (table 4). Overall, the Type A seals represent approximately 40 percent of the samples collected (11 of 26) and largely consist of rock visually characterized as claystone and limestone, but also include a few of the argillaceous siltstone and argillaceous sandstone samples. The porosity in the Type A seals ranges from 1.22 percent (Kamishak limestone) to 20.2 percent (Bear Lake argillaceous siltstone); in all cases the rocks have a fine-scale pore structure that supports high capillary pressures. 


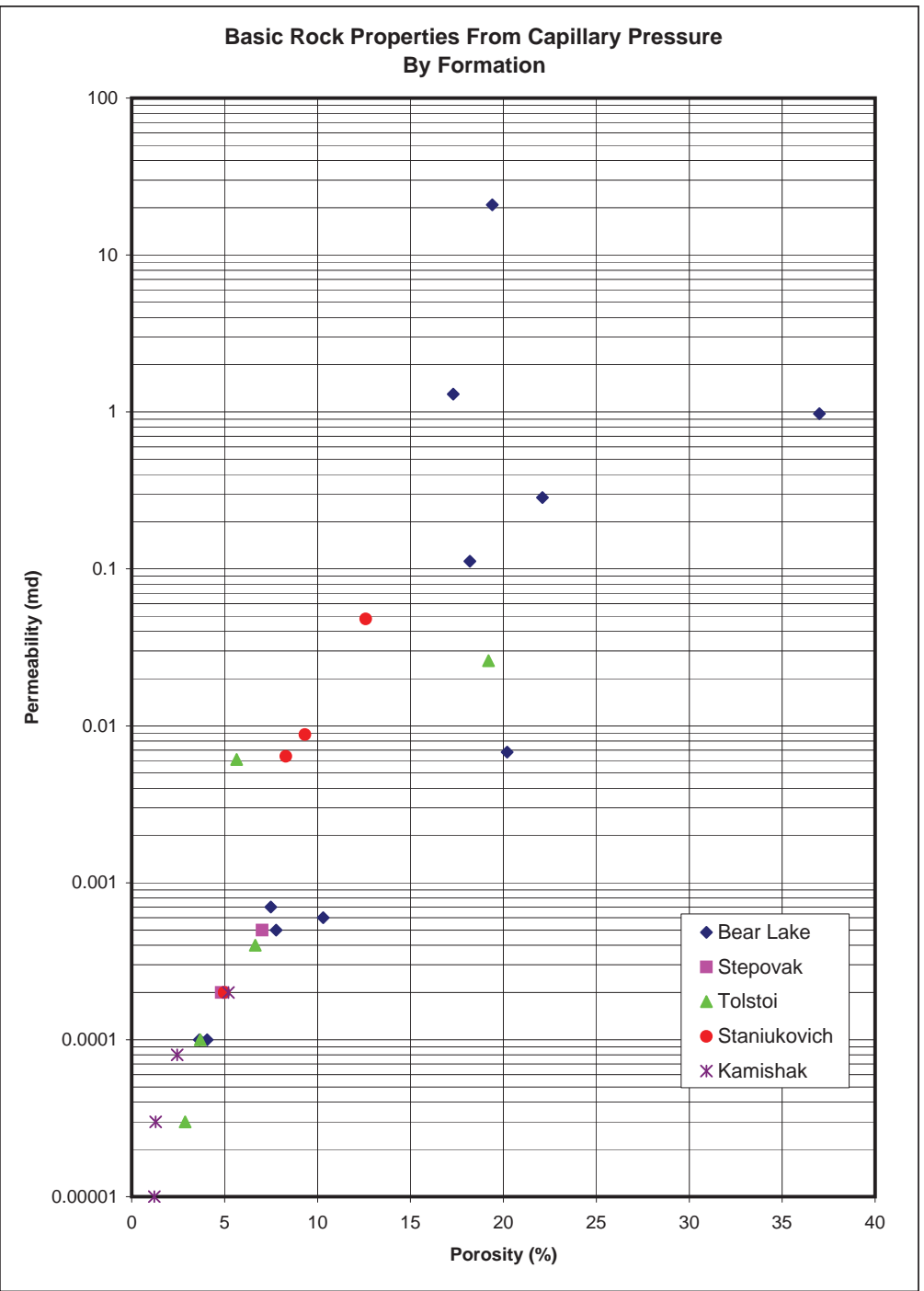

Figure 3. Porosity and permeability derived from mercury injection capillary pressure analyses of 26 Alaska Peninsula outcrop samples. Samples are plotted using symbology corresponding to their stratigraphic formation and show significant variability due to rock type changes and petrophysical differences within the individual formations.

Table 3. Sneider (1997) hydrocarbon seal types, mercury entry pressure, and range in oil column held based on mercury injection capillary pressure (MICP) analyses.

\begin{tabular}{ccc} 
Seal Type & $\begin{array}{c}\text { Entry Pressure (pounds } \\
\text { per square inch) }\end{array}$ & $\begin{array}{c}\text { Oil Column Held (feet; } \\
\text { one meter } ~ 3.1 \text { feet) }\end{array}$ \\
$\mathrm{A}+$ & $>6,868$ & $>5,000$ \\
$\mathrm{~A}$ & $1,373-6,868$ & $1,000-5,000$ \\
$\mathrm{~B}$ & $687-1,373$ & $500-1,000$ \\
$\mathrm{C}$ & $137-687$ & $100-500$ \\
$\mathrm{D}$ & $69-137$ & $50-100$ \\
$\mathrm{E}$ & $14-69$ & $<50$ \\
$\mathrm{~F}$ & $<14$ & Waste Zone \\
\hline
\end{tabular}


Figure 4. Porosity and permeability derived from mercury injection capillary pressure analyses of 26 Alaska Peninsula outcrop samples. Samples are plotted using symbology corresponding to their Sneider (1997) hydrocarbon seal type (see text and table 3 for details).

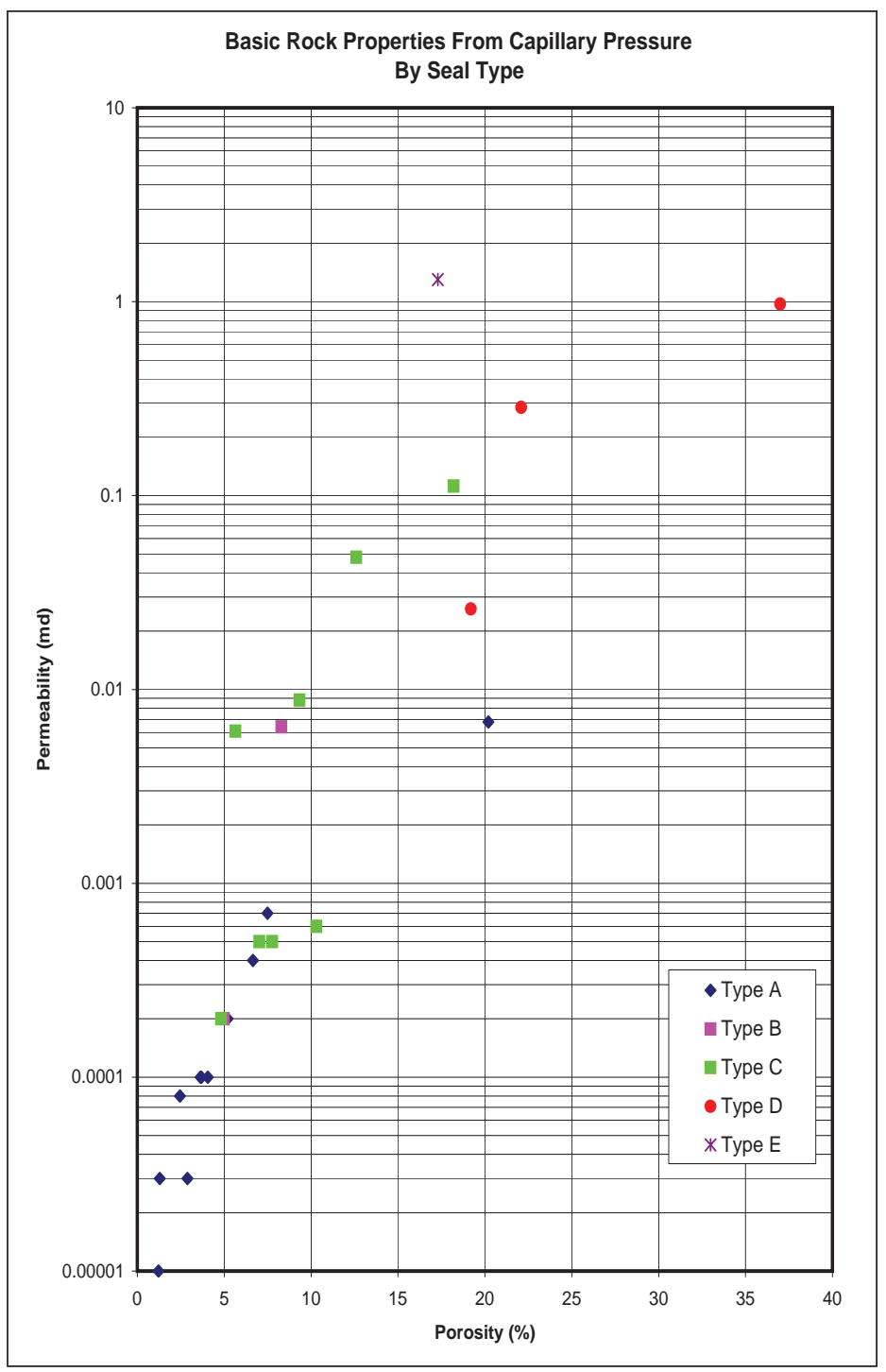

Table 4. Sneider (1997) hydrocarbon seal types, Alaska Peninsula formations sampled and hydrocarbon column height values for oil and gas based on mercury injection capillary pressure (MICP) analyses.

\section{Seal Formations \\ Type Present}

A Bear Lake

Kamishak

Tolstoi

B Staniukovich

C Bear Lake

Staniukovich

Stepovak

Tolstoi

D Bear Lake

Tolstoi

E

Bear Lake
Column height range (feet; 1 meter $~ 3.1$ feet)

\section{Oil}

$2,170-4,984$

$798-1,360$

$199-661$

$117-151$

61
Column height average (feet; 1 meter $~ 3.1$ feet )

Oil Gas

3,257

2,404

1,079

796

$589-1,004$

$147-488$

417

308

$87-111$

136

101 
Type $\mathrm{C}$ seals are the next most common and account for approximately 30 percent of the samples. They are present in all of the formations except the Kamishak and, for the most part, are moderately argillaceous to argillaceous siltstones. A majority of the Type $\mathrm{C}$ seal rocks have a bimodal pore structure and the lower capillary pressures associated with the larger, initial pore aperture population generally control the seal capacity. Where the Type $C$ seals have a laminated fabric that creates the bimodality, the seal quality may be higher if the laminations are oriented perpendicular, or at a high angle, to the hydrocarbon migration direction, like a top seal that is conformable with the reservoir. Porosity ranges from 4.82 percent (Stepovak Formation) to 18.2 percent (Bear Lake Formation).

The Staniukovich Formation samples include a calcareous siltstone with cemented to partially open fractures, and a well compacted sandstone that are both Type B seals. Porosity is 8.30 percent and 4.98 percent, respectively. These rocks have bimodal pore structures that do not appear to be related to the depositional fabric.

A small portion of the samples collected represent Type D and E quality seals. The Bear Lake Formation rocks within these lower seal capacity ranges, for the most part, have grain-supported fabrics and appear to contain an amount of open intergranular pore space that makes them borderline reservoir rock, rather than seals. They also have high porosity (17.3 to 37.0 percent) and permeability (0.285 to $1.30 \mathrm{md})$. However, as with the Type $C$ seals, laminated fabrics and bimodal pore structures present the potential for higher seal quality if the laminations are perpendicular to the migration direction. In the Tolstoi Formation an apparently organic-rich, almost coaly, claystone was sampled that has high porosity (19.2 percent) and a heterogeneous pore structure that produces capillary properties consistent with a Type D seal.
The seal capacity (hydrocarbon column held) can be quantified based on an assumption of the hydrocarbon saturation present in the seal at the leak point. The air/mercury capillary pressure needed to generate the assumed saturation is converted to equivalent height for the specific hydrocarbon/water system being evaluated. The common range in values is from 5 to 10 percent non-wetting phase saturation. The value at 7.5 percent saturation is used here to indicate the point at which the hydrocarbon content in the seal is sufficient to form a phase continuous enough to cause the seal to leak. Potential seal capacities for this saturation level, grouped by formation, are plotted in figures 5 and 6 for oil and gas, respectively.

It is apparent from the seal capacity data in figures 5

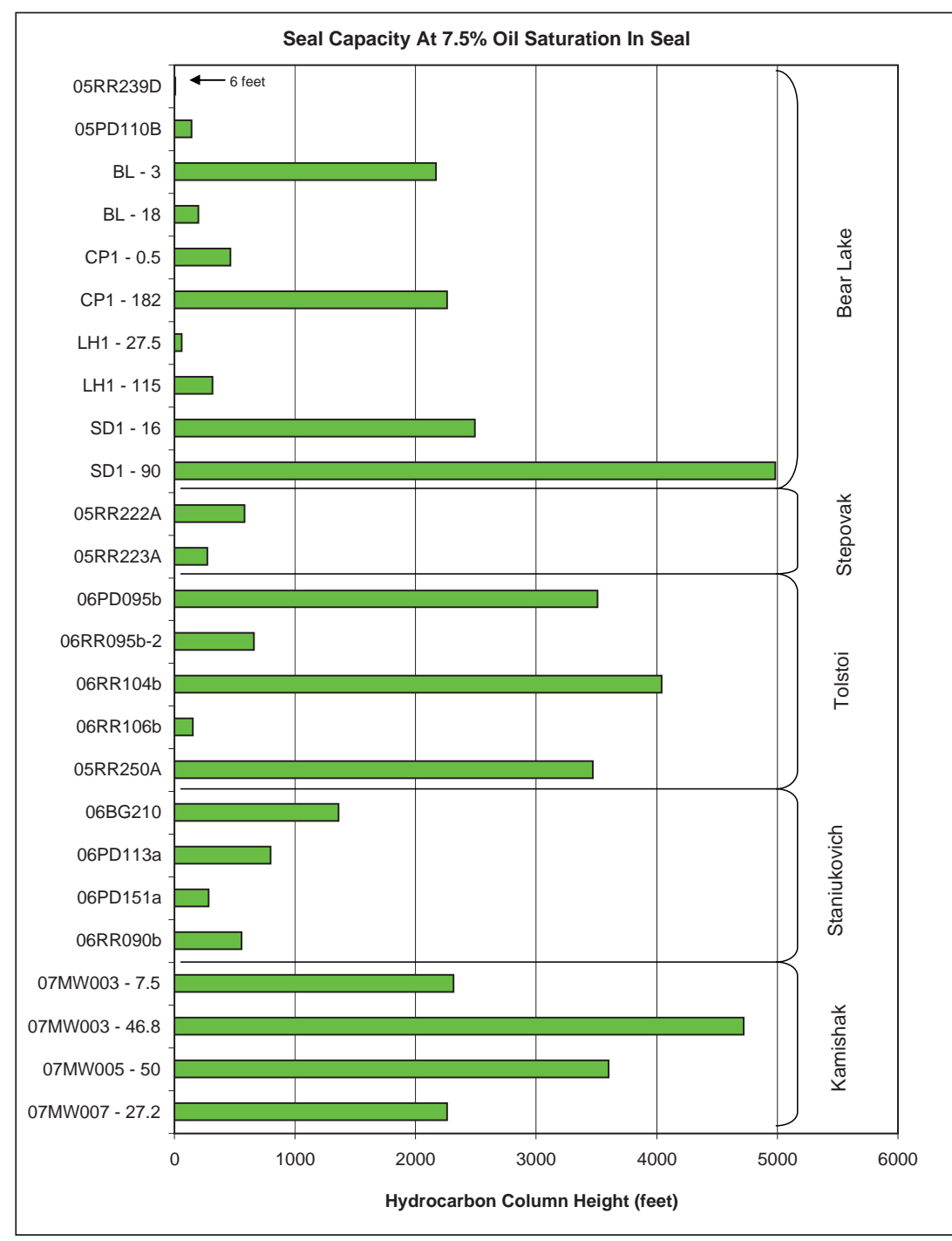

Figure 5. Seal capacity (at 7.5 percent oil saturation in seal) for 26 Alaska Peninsula outcrop samples. Mercury injection capillary pressure analyses show significant variability in the potential column heights for the rock types sampled as well as within the individual formations. 
and 6 that there is significant variability in the potential column heights for the rock types sampled and also within the individual formations. Table 4 illustrates the range in potential column heights for both oil and gas referenced to the Sneider Seal Types.

\section{CONCLUSIONS}

The results of the mercury injection analysis show that there are rock types that represent good quality capillary seals present in Miocene- to Triassic-age formations of the Alaska Peninsula (onshore Bristol Bay petroleum system). The highest quality seals are found in the Kamishak, Tolstoi, and Bear Lake Formations, and the poorest in the Stepovak and Staniukovich. However, as sampled, there is also significant variability within some of the formations, with some of the poorest quality seals also coming from the Bear Lake and Tolstoi Formations.

The rock types analyzed include siltstone, sandstone, claystone, and crystalline limestone. Porosity ranges from 1.22 to 37.0 percent and permeability from 0.00001 to $1.30 \mathrm{md}$. The siltstones and sandstones are commonly moderately argillaceous to argillaceous, and are thinly laminated in the Bear Lake Formation. The laminae are developed by changes in particle size and/or clay mineral content.

Nearly half (40 percent) of the rocks analyzed are Type A seals (Sneider Classification System) that comprise crystalline limestones (Kamishak Formation), claystones (Tolstoi and Bear Lake Formations), and compacted/cemented sandstones (Bear Lake and Kamishak Formations). Using "standard" reservoir fluid parameters, the average capillary properties of the Type A seals are capable of holding oil columns of 3,200 ft and gas columns of 2,400 ft. Lower quality Type B seals are represented by compacted/cemented sandstone and siltstone (Staniukovich Formation) with slightly more open pore structures, or that contain partially open fractures.

Type C seals are the second most common seal type and compose about 30 percent of the samples. As with most depositional systems, an increase in the grain content of the rock generally results in a decrease in seal quality, especially where the rock fabrics develop a grain-supported framework. In this study, the more grain-rich rocks, sampled from the Bear Lake, Staniukovich, Stepovak, and Tolstoi Formations, include siltstones and sandstones that contain varying amounts of matrix clay. Additionally, a portion of the Type $C$ seals have laminated fabrics that commonly result in bimodal pore structures; where the more permeable lami-
Figure 6. Seal capacity (at 7.5 percent gas saturation in seal) for 26 Alaska Peninsula outcrop samples. Mercury injection capillary pressure analyses show the significant variability in the potential column heights for the rock types sampled and also within the individual formations. 
nae with larger pore apertures control the seal quality. As tested, the Type $\mathrm{C}$ seals can trap potential oil columns of $400 \mathrm{ft}$ and gas columns of $300 \mathrm{ft}$. However, in the laminated rocks, seal quality should improve if the laminae are oriented perpendicular, or at high angles, to the direction of hydrocarbon migration, like a top seal that is conformable with the reservoir.

The most grain-rich rock sampled, including those with open intergranular pore structures more comparable to reservoir rock, make up the limited number of Type $\mathrm{D}$ and E seals.

\section{REFERENCES CITED}

Loveland, A.M., Reifenstuhl, R.R., Gillis, R.J., and Decker, P.L., 2007, Outcrop sample results from mercury injection capillary pressure analyses, Bristol Bay, Alaska Peninsula: Alaska Division of Geological \& Geophysical Surveys Raw Data File 2007-3, 11 p.

Sneider, R.M., 1997, Petrophysical properties of seals, in Surdam, R.C., ed., Seals, traps and the petroleum system: Tulsa, OK, American Association of Petroleum Geologists Memoir 67, 317 p.

Swanson, B.F., 1981, A simple correlation between permeabilities and mercury capillary pressures: Journal of Petroleum Technology, p. 2,498-2,504. 